\title{
EVALUATING THE IMPACT OF SUSTAINABILITY ON INVESTMENT PROPERTY PERFORMANCE
}

\author{
TERRY BOYD \\ Central Queensland University and Queensland University of \\ Technology
}

\begin{abstract}
There is general agreement that environmental and social features, particularly those improving health and productivity of workers, will impact on the functionality of investment property. However there has been a range of opinions on whether this impact can currently be quantified through a valuation exercise (Lutzkendorf and Lorenz (2005), Sayce, Ellison and Smith (2004)).

This paper examines the current literature on the assessment of the impact of environmental and social characteristics on investment property. It adds to the debate on the need for advanced techniques to assess the triple bottom line and identifies the key performance indicators that require measurement. An appropriate methodology to assess the triple bottom line result is described. The paper also incorporates a triple bottom line case study assessment in Brisbane, Australia, that demonstrates the ability of the cash flow approach to assess the worth of environmental and social characteristics. In conclusion, the paper identifies the additional data and research required to assess the worth of investment property using a triple bottom line approach.
\end{abstract}

Keywords: Triple bottom line, environmental benchmarks, social indicators, cash flow valuation, simulation, contingent valuations.

\section{INTRODUCTION}

Sustainability is currently one of the most popular research fields for academics. It has become the catchword for most new concepts and it has strong emotional and ethical connotations. There is clear evidence that human behaviour has severely damaged the earth's ecosystems and that, looking forward, there is a need to ensure that future generations are not compromised by our actions today. 
The impact of sustainability on real property is a major concern at present, but it is unfortunate that sustainability has, in many cases, been trivialised by overemphasis and generalisation. Real property takes its worth from its utility and the impact of humans on property directly affects its sustainability. Understandably, there is growing recognition that property development and management should be evaluated against criteria that embody sustainability measures. This means that genuine sustainability evaluations will balance economic and social performance measures with environmental protection. This is the triple bottom line (TBL) evaluation approach.

The TBL evaluation approach has, historically, had little impact on the property market place; possibly because there has been no substantial change driver to broaden the existing financial dominance in the assessment process. While incremental regulatory changes may force the market place to make some improvements, existing regulations have not caused investors and developers to change their fundamental approach to focusing on the bottom line.

The author believes it is the space occupier, the tenant or lessee, who will cause the shift to more healthy and productive buildings. This will not simply mean an improvement in the indoor air or lighting quality, but rather a much broader demand for comfortable, userfriendly and adaptable space. In other words, improvements in environmental factors are not enough, there must also be major improvement in social and cultural aspects of the built environment.

While the trend towards accommodating more user-focused demand has started, it is difficult to evaluate its impact on the market place, as there is very little historical evidence. Despite the difficulties, we must attempt to evaluate the emerging impact of these sustainability factors, and as they will influence the decision of space occupiers to lease or not to lease and also to set the acceptable level of rental.

It raises the question of whether we can, realistically, quantify the impact of environmental and social characteristics on investment property. If so, what will be the impact on investment property performance?

This paper is focused on this challenge. Initially, it considers the impact of sustainability on valuation methodology - the assessment of the Triple Bottom Line (TBL) - and whether the traditional valuation methodology can assess the TBL. This leads to the identification of measurable indicators for the environmental and social characteristics. Thereafter, the impact of the various indicators on the financial model is discussed with reference to current studies. Finally, a pilot case study is presented that is based on market data and a preliminary survey. The results of the study quantify the probable impact of enhanced environmental and social factors on the expected return from commercial buildings. Simulation is used to estimate the risk/return profiles of the different scenarios. The results of the cash flow exercises should be treated with caution because of the limited available data and the ongoing need to refine and expand this research field. 


\section{EVALUATING SUSTAINABILITY IN PROPERTY PERFORMANCE}

Concepts of sustainable development have been highlighted over the past 25 years. Stern (1997) refers to the World Conservation Strategy put forward by the International Union for the Conservation of Nature in 1980. The impact of buildings on the environment has been researched over this period with findings from the USA that non-residential buildings:

- Consume $30-40 \%$ of all the nation's energy

- Add 30-40\% to atmospheric emissions

- Use $60 \%$ of all electricity

- Use $25 \%$ of all water

- Take up 35-40\% of the municipal solid waste stream

$$
\text { (von Paumgarten, 2003, p.26) }
$$

However, there is limited empirical research into the impact of environmental and social factors on the economic performance of property assets. The reasons for this will be further discussed below.

The impact and assessment of sustainability on building design and construction is a fertile area of research and many interesting findings are being published in journals such as Building Research and Information. In a paper on building environmental assessment methods, Cole (2005) describes the maturation of building environmental assessment methods over the past fifteen years, but rightly comments:

Given the uncertainties of climatic change and associated social, economic and political consequences, there will be no single or easy path to a sustainable future.(p. 460)

Other disciplines allied to the property industry are also debating the impact of sustainability, such as the fields of Planning, Economics, Facilities Management - refer Griffiths (2003), Stern (1997), von Paumgarten (2003), Bakens et al (2005). Most of the authors emphasise the complexity of the evaluation process and the need to consider the interests of the key stakeholders.

The question is often raised in the literature whether it is feasible, at present, to evaluate the impact of sustainability on investment property assets. Without doubt, corporations are including a focus on sustainability in their strategies and there is growing interest from the public in socially responsible entities. Cassidy (2004) states that by 2010:

Ninety percent of Fortune 500 companies will adopt the so-called "triple bottom line reporting". The growth of interest in green building among major corporations is one expression of this phenomenon.(p. 5) 
Several property valuation specialists are examining the ability to evaluate TBL techniques for investment property. In the United Kingdom, the Royal Institution of Chartered Surveyors has sponsored work in the field and the research findings by the Upstream Group (2003) and Kingston University (Sayce and Ellison, 2003) are noteworthy. Sayce and Ellison use the traditional cash flow approach to assess the market value of property when different sustainability criteria are incorporated.

More recently, Lutzkendorf and Lorenz (2005) examined the valuation approach for sustainable buildings. They consider that traditional valuation methods may not be suitable for valuing a building's performance to meet environmental and social requirements. They state:

Relying on historical valuation methods will lead to an unbalanced approach for determining a property's exchange price or market value.(p.228)

They continue that the 'worth' from the viewpoint of the user should be examined and recommend advanced valuation methods such as "artificial neural networks, hedonic pricing methods, special analysis, fuzzy logic, autoregressive integrated moving averaging and rough set theory" (p.228). They place emphasis on the hedonic pricing techniques, but note the difficulties of describing and assessing the different building features and the lack of large and appropriate data sets. They also consider that "many valuers might not have the facilities, required skills and probably motivation to use those techniques. They are therefore likely relying on traditional valuation approaches in the foreseeable future" (p.229).

The challenge by Lutzkendorf and Lorenz means that the appropriateness of the traditional investment approach for a TBL application should be critically examined. The traditional approach, for major investment properties, is the discounted cash flow approach that identifies the expected cash flow from the property over a future period of time and then assesses the current value or the total return over the selected period. This approach can accommodate the different sustainability scenarios by varying the key inputs for differing environmental or social benchmark levels. However, life cycle costings and assessments are limited to the period of the cash flow study, often five to ten years. The advanced valuation methods described by Lutzkendorf and Lorenz may be capable of quantifying the impact of specific environmental or social factors, provided adequate market data can be identified and analysed.

The author believes that the traditional investment valuation method is capable of assessing the impact of environmental and social factors on the financial performance and that the advanced methods do not replace the traditional approach. When reasonable market data on the impact of the environmental and social factors is available, which is not the case at present, the advanced methods may supplement the traditional method, but they are unlikely to replace it.

The balance of this paper will demonstrate the use of the traditional investment valuation method to assess the alternative performance measures of investment property if the triple 
bottom line approach is included or excluded. However, prior to discussing the valuation exercise, it is necessary to identify the environmental and social factors and their performance indicators.

\section{THE ENVIRONMENTAL AND SOCIAL BENCHMARKS}

Valuable work identifying appropriate environmental indicators for built assets has already been undertaken internationally. Most developed countries have established Green Building Councils that, in turn, have structured environmental benchmarks. In Australia, the Green Building Council of Australia (CGCA) has developed a Green Star rating system and there are other similar assessment models. The USA has, inter alia, the Leadership in Energy and Environmental Design (LEED) Green Building Rating System and the UK has the Building Research Establishment Environmental Assessment Method (BREEAM).

However, many of the building measures deal with design and new construction and lesser consideration has been given to existing building stock as operating entities. Cole (2005) describes measures from many countries such as Japan, Hong Kong and South Africa and comments that:

There is little doubt that building environmental assessment methods have contributed enormously to furthering the promotion of higher environmental expectations and are directly and indirectly influencing the performance of buildings. (p. 456)

As this study is undertaken in Australia, it is logical to examine the Green Star Rating of GBCA and the emerging combined environmental rating measures being researched by the Australian CRC in Construction Innovation. The Green Star environmental rating system is described by the GBCA as:

Australia's first comprehensive rating system for evaluating the environmental design and performance of Australian buildings based on a number of criteria, including energy and water efficiency, indoor environmental quality and resource conservation. (p.1)

The Green Star rating system has eight environment impact categories which are: Energy, emissions, transport, materials, water, land use and ecology, indoor environment quality, and management.

The GBCA's office rating tool formed the basis for the environmental factors selected in the CRC-Construction Innovation's research project on "The Evaluation of the Functional Performance of Commercial Buildings" (2004) which is earlier research undertaken by the author and industry partners. The CRC project also considered the work undertaken by Environment Australia (2003) and by several UK organisations including the Upstream Group (2003) and Sayce and Ellison (2003). 
While environmental benchmarking is well advanced, the benchmarks for social factors are not yet established. Many existing benchmarks include some social characteristics within the environmental benchmarks, such as Sayce and Ellison (2003) and Lutzkendorf and Lorenz (2005). The author considers that it is necessary to have a distinct set of benchmarks for social factors in order to examine the meaningful triple bottom line assessment of built assets.

The environmental and social benchmarks developed and tested in the CRC Construction Innovation Project (2004) are used in this study and these benchmarks are set out in Figures 1 and 2. 
Figure 1: Recommended Environmental Benchmarks: Existing Buildings

\begin{tabular}{|c|c|}
\hline FIELD/TOPICS & MEASURES \\
\hline \multicolumn{2}{|l|}{$\begin{array}{l}\text { Resource } \\
\text { Consumption }\end{array}$} \\
\hline Energy & $\begin{array}{l}\text { - net fossil fuel energy use (assessed on an intra-building and market } \\
\text { comparison basis) } \\
\text { - effective action to reduce greenhouse gas emissions (particularly from } \\
\text { energy use) } \\
\text { - office lighting power density and peak energy demand reduction strategies } \\
\text { - evidence of alternative energy supplies from renewable sources or from } \\
\text { cogeneration }\end{array}$ \\
\hline Air-conditioning & $\begin{array}{l}\text { - condition of air-conditioning plant } \\
\text { - use of ODP or GWP refrigerants }\end{array}$ \\
\hline Water & $\begin{array}{l}\text { - water consumption (potable, hygiene and cooling towers), } \\
\text { - recycling and water capture measures } \\
\text { - wastewater reduction } \\
\text { - hazardous and non-hazardous waste and effluents recycling or removal } \\
\text { strategies }\end{array}$ \\
\hline \multicolumn{2}{|l|}{$\underline{\text { Design and Use }}$} \\
\hline Transport & $\begin{array}{l}\text { - public transport availability and standard of service } \\
\text { - strategies to discourage single occupancy vehicle journeys, including cyclist } \\
\text { facilities }\end{array}$ \\
\hline Building fabric & $\begin{array}{l}\text { - } \text { age of building (obsolescence or depreciation of materials) } \\
\text { - re-use or upgrade history or potential } \\
\text { - } \text { suitability of original materials for refurbishment and façade retention } \\
\text { - ecological impacts of materials used }\end{array}$ \\
\hline Interior & $\begin{array}{l}\text { - indoor quality measured by ventilation, natural lighting, individual thermal } \\
\text { control, noise abatement } \\
\text { - absence of indoor air pollutants }\end{array}$ \\
\hline Environment & $\begin{array}{l}\text { - quality of overall built environment and site use in relation to aesthetics, } \\
\text { visual blending and connection contribution of its street frontage and wider } \\
\text { precinct }\end{array}$ \\
\hline \multicolumn{2}{|l|}{ Governance } \\
\hline Awareness & $\begin{array}{l}\text { - maximisation by management of the potential of the environmental design } \\
\text { features through awareness programs }\end{array}$ \\
\hline Disclosure & $\begin{array}{l}\text { - disclosure and transparency of environmental data, regulation compliance, } \\
\text { awards, and environmental expenditure of any type. }\end{array}$ \\
\hline
\end{tabular}


Figure 2: Proposed Social Benchmarks: Existing Buildings

\begin{tabular}{|c|c|}
\hline TOPIC & MEASURES \\
\hline Health and Safety & $\begin{array}{l}\text { - compliance with H \& S regulations and appropriate signage } \\
\text { - adequate public liability and service provider insurance } \\
\text { - awareness and training of emergency evacuation and accident } \\
\text { first aid procedures for all floor wardens } \\
\text { - a first aid station accessible to all building users }\end{array}$ \\
\hline Stakeholder Relations & $\begin{array}{l}\text { - monitoring of stakeholder concerns, views and provisions } \\
\text { - transparency and disclosure of landlord/tenant contracts and } \\
\text { marketing agreements } \\
\text { - supportive use and occupation guidelines for tenants } \\
\text { - appropriate training for security and public relations } \\
\text { personnel }\end{array}$ \\
\hline Community Engagement & $\begin{array}{l}\text { - encouragement of employment of local residents within the } \\
\text { building } \\
\text { - provision of accessible public facilities } \\
\text { - promotion of and linkage to local service providers } \\
\text { - accessible communication channels with building } \\
\text { stakeholders }\end{array}$ \\
\hline Accessibility & $\begin{array}{l}\text { - } \text { connections to designated green spaces } \\
\text { - proximity to urban spaces (town centres, malls, etc) } \\
\text { - wheelchair access } \\
\text { - proximity to childminding facilities }\end{array}$ \\
\hline $\begin{array}{l}\text { Occupier Satisfaction and } \\
\text { Productivity }\end{array}$ & $\begin{array}{l}\text { - quality of communal service areas } \\
\text { - complementary usage of building (compatible tenants) } \\
\text { - occupant productivity in terms of satisfaction and physical } \\
\text { wellbeing }\end{array}$ \\
\hline Cultural Issues & $\begin{array}{l}\text { - recognition of indigenous people through cultural space and } \\
\text { communication of site history } \\
\text { - consideration of gender equity and minority group } \\
\text { requirements } \\
\text { - preservation of heritage values } \\
\text { - value of artwork as percentage of the fit out }\end{array}$ \\
\hline Local Impacts & $\begin{array}{l}\text { - aesthetic implications (compliance with precinct theme, } \\
\text { building scale, etc.) } \\
\text { - practical implications (traffic generation, off-street emergency } \\
\text { parking and pedestrian management) } \\
\text { - nature of tenant businesses and naming rights } \\
\text { - community linkages and sponsorship of local neighbourhood } \\
\text { activities }\end{array}$ \\
\hline
\end{tabular}


It is accepted that the specification of environmental and social indicators can take many forms. The tables above represent one attempt to identify the major characteristics of an operational nature with particular reference to the utility of the building. The selection of benchmark indicators should be evaluated against the market's perception of value of the individual measures. Once the appropriate indicators and their component characteristics have been selected, the next challenge is to determine a grading or weighting for the indicators.

The environmental benchmarks, described in Figure 1, were used in the case study (described later), but the author considers that future research should utilise the one of the acceptable industry rating systems, such as the GBCA's Green Star rating system for "Offices as built" (www.abcaus.org - rating fact sheet).

When considering the social indicators, as shown in Figure 2, the ranking of the measurement categories were examined by surveying several building managers and users. Each measure was assessed using a 5 point Likert scale and the scores were summed to identify possible ranking and weighting. However the lack of clarity and consistency meant that no discernable pattern was achieved and consequently, at this developmental stage, it was decided that the social measures could only be applied on a broad scale with buildings being placed in three categories, being:

1. not socially responsible

2. acceptable socially responsible standard - for a private corporation or individual

3. acceptable socially responsible standard - for a public body.

When testing the triple bottom line effect in the case study, it was decided to limit the grading of each social measure to a two-way alternative, being either "enhanced" or "not enhanced". This simple alternative was used because of the difficulty of finding the impact of varying levels of social enhancement for each measure. Before considering this case study, the international research in this field is described.

\section{TRIPLE BOTTOM LINE EVALUATIONS - CURRENT LITERATURE}

The impact of sustainability measures on the return from investment property is, clearly, an important issue for investors. They need to know whether the application of advancements in environmental and/or social factors will result in improved returns from the property assets.

In short, the current literature is inconclusive at present. Brenchley (quoted in Ryder 2004) predicts that with an increasing number of ethical investment funds emerging, it is inevitable that investors will begin to look more seriously at property over the next 5 to 10 years, and that this increased demand for environmentally and socially sustainable 
buildings is likely to result in premium values. Even now, a good energy rating on a building may give it a market edge. There is some evidence that for public sector tenants at least, a fall in the rating during tenancy can actually trigger a diminution in rent. An example is a New South Wales Police Services lease with Multiplex that states that the rent will be reduced if the building's 4.5 star rating falls (Dorfling 2004). This suggests that a premium rent may be achieved based on an expectation of lower occupancy costs or a better working environment.

Research into the impact of TBL considerations has been undertaken in both the USA and the UK. A report to California's Sustainable Building Task Force (Kats 2003) quantifies the costs and financial benefits of Green Buildings. It places a strong focus on productivity and health and quotes from the BOMA/ULI (1999) Office Tenant Survey Report that:

"Survey respondents attributed the highest importance to tenant comfort features, including comfortable air temperature (95\%) and indoor air quality (94\%). Office temperature and the ability to control temperature are the only features that were both 'most important' and also on the list of things with which tenants are least satisfied."

The survey also found that the other feature that the tenants valued highly was intelligent building features.

The finding of the report to SBTF (Kats 2003) was that the financial benefits of building green include savings from reduced energy, water and waste; lower operation and maintenance costs; and enhanced occupant productivity and health. The findings of the report are summarized in Figure 3.

Figure 3: Financial Benefits of Green Buildings: Summary of findings)

\begin{tabular}{|l|l|}
\hline Category & $\mathbf{2 0}$ year NPV \\
\hline Energy Value & $\$ 5.79 / \mathrm{sq} \mathrm{ft}$ \\
\hline Emissions value & $\$ 1.18 / \mathrm{sq} \mathrm{ft}$ \\
\hline Water value & $\$ 0.51 / \mathrm{sq} \mathrm{ft}$ \\
\hline Waste value (construction only) - 1 year & $\$ 0.03 / \mathrm{sq} \mathrm{ft}$ \\
\hline Commissioning O \& M value & $\$ 8.47 / \mathrm{sq} \mathrm{ft}$ \\
\hline Productivity and Health value (Certified and Silver) & $\$ 36.89 / \mathrm{sq} \mathrm{ft}$ \\
\hline Productivity and Health value (Gold and Platinum) & $\$ 55.33 / \mathrm{sq} \mathrm{ft}$ \\
\hline Less Green Cost Premium & $\mathbf{( \$ 4 . 0 0 ) / \mathrm { sq } \mathrm { ft }}$ \\
\hline Total 20 year NPV (Certified and Silver) & $\mathbf{\$ 4 8 . 8 7 / s q ~ f t ~}$ \\
\hline Total 20 year NPV (Gold and Platinum) & $\mathbf{\$ 6 7 . 3 1 / s q ~ f t ~}$ \\
\hline
\end{tabular}

Source: Capital E Analysis - in Kats (2003, p. 84) 
While this study refers to a tenfold benefit on the initial estimate of the cost premium, the figures indicate that the majority of the benefits will come from "productivity and health value", being $70 \%$ of the total benefit for certified and silver class, and $87 \%$ for gold and platinum class. The report refers to the difficulty of assessing the productivity and health value components within this exercise and this means that the results should be viewed with caution. The author considers that the most appropriate way to assess the productivity and health value is to find rental evidence from the market place and that the large productivity and health benefits require further examination.

Another recent study looks at the impact of sustainability standards when assessing the market value of property assets. This research by Sayce, Ellison and Smith (2004) is a continuation of their Sustainable Property Appraisal Project and describes the findings of their pilot studies on four different properties. They adjust four key variables (rental growth, depreciation, risk premium and cash flow) for various sustainability criteria. The sustainable criteria weighting in this exercise is shown in Figure 4.

\section{Figure 4: Weighting of Sustainable Criteria}

\begin{tabular}{|l|l|}
\hline Sustainable Criteria & Weighting \\
\hline Assessibility & 1.0 \\
\hline Building quality & 0.9 \\
\hline Adaptability & 0.8 \\
\hline Occupier satisfaction & 0.7 \\
\hline Pollutants & 0.6 \\
\hline Contextual fit & 0.5 \\
\hline Energy efficiency & 0.4 \\
\hline Water and waste & 0.3 \\
\hline Occupier impact & 0.2 \\
\hline \multicolumn{2}{|c|}{ Source: Sayce, Ellison and Smith $(2004, \mathrm{p} .227)$} \\
\hline
\end{tabular}

They assess the value of each property using standard valuation factors and thereafter using the weighted sustainability criteria in addition to the standard valuation factors. Their finding is that the incorporation of the weighted sustainability criteria reduces the value of any property that fails to meet sustainability criteria. They conclude:

The new net present values produced in these examples suggest the standard appraisal process is over-valuing, if sustainability is taken into account. (Sayce et al, 2004, p. 233) 
The results of the Sayce et al study are interesting and progress the research in this field. The author's concern with the alternative valuation approach (that adjusts for sustainability criteria) is that the rent currently being paid relates to the existing level of sustainability of the building. If the building had a higher level of sustainability the rental level may be higher. Therefore, it could arguably be suggested that the "less sustainable" building is correctly valued by the market and that a "more sustainable" building would have a higher value.

\section{EVALUATING THE IMPACT OF ENVIRONMENTAL AND SOCIAL MEASURES}

There is little doubt that environmental and social measures will have an impact on investment property performance. An illustration of the probable impact of enhanced environmental characteristics on investment-type buildings is shown in Figure 5.

\section{Figure 5: Value Impact of Environmentally Efficient Buildings}

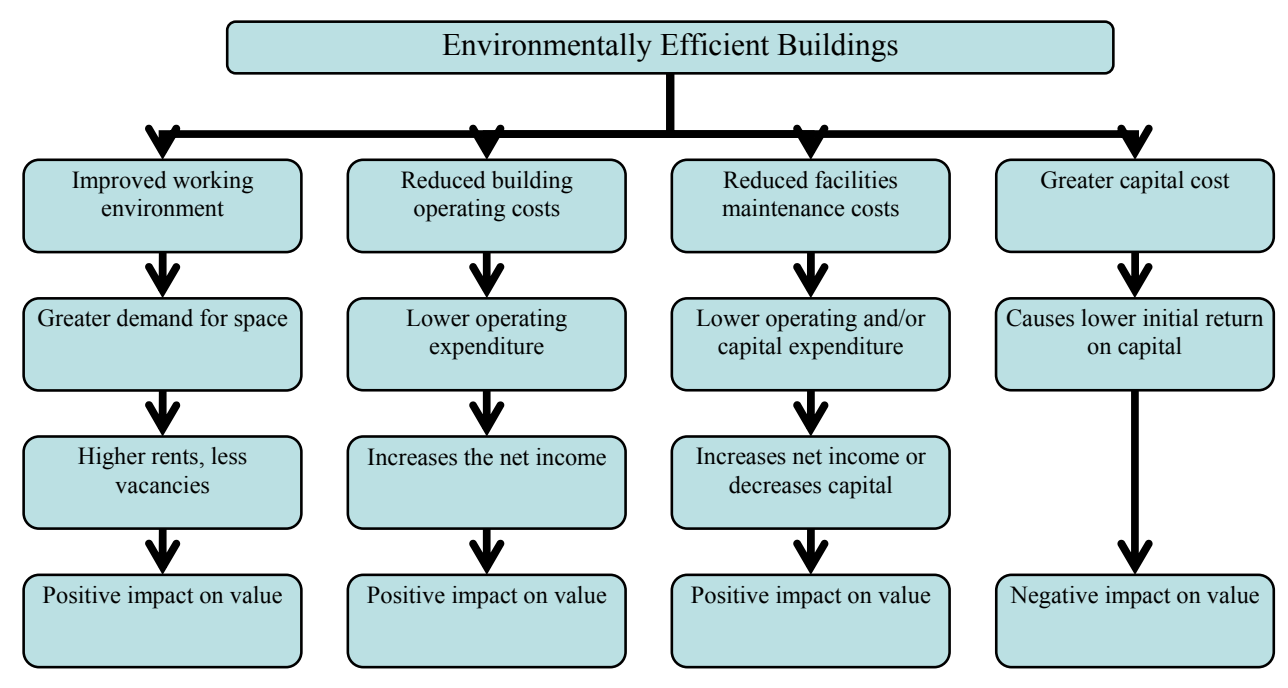

Source: Author

Figure 5 indicates that there are four expected results from greater environmental efficiency and that three of the four impacts should have a positive effect on the capital value of the building. However, the degree and timing of the impact is complicated and will differ according to the type of environmental improvement. It is too simplistic to conclude that the change will always, or even frequently, have a positive impact on the 
capital value. What is important is that the impact of enhanced environmental factors on space users is explicitly examined.

While acknowledging the fact that it is difficult to find market based evidence of the impact of environmental and social factors on the return from an investment property, the original CRC-CI Project (2004) examined market data that was available in Queensland. Fortunately, this project had the assistance of Queensland Dept. of Public Works, Rider Hunt and Arups in analysing this data.

After completing the CRC-CI project, the author has had further discussions with a group of property managers, valuers and office tenants to gauge their willingness to pay for environmental and social improvements to buildings. This pilot study followed a contingent valuation approach and the results are used in the case study below. The author, probably because of the limited number of these buildings, has found no literature on post-occupancy evaluations on enhanced buildings. A good commentary on the difficulties of occupier comfort indices is given in Humphreys (2005).

In addition, the author discussed the feasibility and cost of environmental and social criteria with building owners in order to estimate the impact of these factors on the performance of commercial buildings. However, there is very limited market data on the performance of environmentally and/or socially enhanced buildings to support the opinions of property experts. Consequently, the testing of the impact of the indicators has been restricted to a pilot study. This examines whether a cash flow valuation model, as used in the market to assess the financial performance of investment property, is capable of determining the triple bottom line measure. In addition, the study will assess the risk parameters of the different scenarios based on probability profiles of the key variables.

\section{CASE STUDY}

The case study building is an existing prime office building in Brisbane CBD, Australia, which was worth approximately $\$ 112 \mathrm{M}$ in July 2005 . The building is ten years old and is expected to show a total return of approximately $9.5 \%$ return over the next seven years.

The first step of the exercise was to identify the key input variables that would be affected by environmental or social enhancement of the building. Five key variables were selected and identified as: the construction cost, the initial (current) rent level, the rental growth rate, the operating expenses and the capital expenses. Thereafter, the author undertook a contingent valuation approach with an industry focus group of six property professionals (managers, valuers and lessees) in order to assess the impact of enhanced environmental and social features on this office building. In this study, enhanced features were classified as equivalent to a 4 star rating, or above, for environmental features and "socially responsible standard (private owner)" for social features. 
Because of the hypothetical nature of the questions, several generalisations were made and there was a high degree of subjectivity. It was necessary to average the range of responses from the professionals and the results are shown in Figure 6.

Figure 6: Breakdown of the Impact of Specific Variables in Cash Flow Study

\begin{tabular}{|l|l|l|l|}
\hline & $\begin{array}{l}\text { Percentage } \\
\text { Variable Change }\end{array}$ & $\begin{array}{l}\text { Percentage } \\
\text { Variable } \\
\text { Change }\end{array}$ & $\begin{array}{l}\text { Percentage } \\
\text { Variable Change }\end{array}$ \\
\hline Input Variable & $\begin{array}{l}\text { Enhanced } \\
\text { Environmental } \\
\text { Features }\end{array}$ & $\begin{array}{l}\text { Enhanced } \\
\text { Social } \\
\text { Features }\end{array}$ & $\begin{array}{l}\text { Combined: } \\
\text { Environmental } \\
\text { and Social } \\
\text { Features }\end{array}$ \\
\hline Construction Cost & $+5 \%$ to $+7 \%$ & $+3 \%$ to $+5 \%$ & $+8 \%$ to $+11 \%$ \\
\hline Initial Rent (first year) & $+3 \%$ to $+5 \%$ & $0 \%$ to $+3 \%$ & $+3 \%$ to $+8 \%$ \\
\hline Rental Growth Rate & $+4 \%$ to $10 \%$ & $+1 \%$ to $+3 \%$ & $+5 \%$ to $+13 \%$ \\
\hline Operating Expenses & $-4 \%$ to $-10 \%$ & $+1 \%$ to $+3 \%$ & $-3 \%$ to $-7 \%$ \\
\hline Capital Expenses & $-2 \%$ to $-10 \%$ & $0 \%$ to $+1 \%$ & $-2 \%$ to $-9 \%$ \\
\hline
\end{tabular}

The ranges of the variable changes shown in Figure 6 refer to the percentage change of that particular variable within a cash flow study of the case study property under the different scenarios. It should be noted that these variables relate to the specific property and will change according to the property type and characteristics of the unenhanced building.

Having undertaken the difficult part of the study, the inputs were applied to cash flow studies to assess the total return from the case study property under four different scenarios. The scenarios were:

1. Existing building condition without environmental or social enhancement

2. The building with enhanced environmental (but not socially enhanced) features

3. The building with enhanced social (but not environmentally enhanced) features

4. The building with both enhanced environmental and social features, the Triple Bottom Line approach. 
A simulation exercise, using @Risk, was undertaken for each scenario, with probability profiles being based on the opinions of the focus group members. The initial cash flow study of the case study property (in its existing condition), over a seven year period using monthly intervals, showed an total annual return from the property of approximately $9.5 \%$. The results from the alternative exercises, incorporating the risk simulation results, are shown in Figure 7.

Figure 7: Changes in Building Performance (IRR) for Enhanced Environmental and Social Features

\begin{tabular}{|l|l|l|l|l|}
\hline $\begin{array}{l}\text { Queensland Case Study } \\
\text { Office Building }\end{array}$ & $\begin{array}{l}\text { Resultant } \\
\text { IRR }\end{array}$ & $\begin{array}{l}\text { Standard } \\
\text { deviation }\end{array}$ & $\begin{array}{l}\text { Range } \\
\text { minimum }\end{array}$ & $\begin{array}{l}\text { Range } \\
\text { maximum }\end{array}$ \\
\hline $\begin{array}{l}\text { In existing condition and net } \\
\text { income }\end{array}$ & $9.53 \%$ & - & - & - \\
\hline $\begin{array}{l}\text { With enhanced } \\
\text { environmental features }\end{array}$ & $9.70 \%$ & $0.15 \%$ & $9.27 \%$ & $10.21 \%$ \\
\hline $\begin{array}{l}\text { With enhanced social } \\
\text { features }\end{array}$ & $9.26 \%$ & $0.12 \%$ & $8.87 \%$ & $9.65 \%$ \\
\hline $\begin{array}{l}\text { With both enhanced } \\
\text { environmental and social } \\
\text { features }\end{array}$ & $9.32 \%$ & $0.13 \%$ & $8.90 \%$ & $9.69 \%$ \\
\hline
\end{tabular}

Figure 7 shows the change in expected return and ranges of the returns under the different scenarios. It will be seen that the case study, with enhanced environmental features, is likely to have an increased return, from $9.53 \%$ to $9.7 \% \mathrm{pa}$, and that the possible range of returns will be between $9.27 \%$ and $10.21 \%$. The other two scenarios, the enhanced social features and the combined TBL features, show the return to be lower than the initial financial return, but there is not a significant difference between them. The case study exercise demonstrates that the mean return with enhanced environmental and social features (TBL) is $9.32 \%$ and that the possible range of returns is $8.90 \%$ to $9.69 \%$. The variability of each exercise is shown by the standard deviation measure and the greatest variation is in the environmental enhancement scenario, because of the larger range of inputs.

The measurement of performance change due to environmental and social enhancement demonstrates that there are several balancing factors in each exercise (more cost and greater net income) and that the resultant returns show limited variations. It is possible that future studies may show greater input variable differences and therefore greater differences between the results of the four scenarios. 
The author's reaction to the case study findings is positive, in that it supports the proposition that sustainability features may not have a major negative impact on property performance. There is also the inference that the impact is likely to be positive in the future. Whilst not supporting some international findings that suggest strong benefits from enhanced sustainability features, this study uses a conservative approach as it is based solely on the measurable impact within a financial study.

The case study exercise has demonstrated that the existing cash flow investment valuation model can be used to assess the TBL value/return. The basic cash flow model is not the main concern with the TBL approach, it is the specification of the inputs (for the specific scenarios) that is difficult to determine from market evidence - more research is required in this field.

\section{CONCLUSIONS AND RECOMMENDATIONS}

The objective of this study was to examine whether the impact of sustainability features on investment property can be quantified and, if so, what is the likely effect? Currently, there is limited international literature that demonstrates the actual impact of sustainability on property asset performance. In addition, there is some concern in the literature that traditional valuation methods are inadequate to undertake this exercise.

This paper concludes that the environmental and social indicators of sustainability can be evaluated using investment cash flow studies and the appropriateness of this methodology is demonstrated in a practical case study. However, there are two difficult steps in the data collection and analysis process that require careful consideration. They are:

1. The identification and quantification of the key performance indicators (KPI) for the environmental and social characteristics, and

2. The measurement of the impact of these environmental and social KPIs on the input variables of the investment cash flow study.

The first step is receiving attention internationally with the environmental standards being reasonably well established, but more work is required on the social standards. The second step is a field that requires further research. The environmental and social features will impact on building costs, operating and capital expenses, as well as rental income. The impact on building cost is relatively easy to assess and the future operating and capital expenses can be estimated through life cycle costing exercises. However, the future rental income is the most difficult variable to assess because of the lack of market evidence.

Further research is required into the willingness of tenants to pay higher rents for space that provides improved health and productivity conditions for space occupants. Both willingness-to-pay and post-occupancy evaluation surveys are needed, because there is 
very little evidence of market rent differentials. With time, this situation will change and we are likely to see the benefits of sustainable features translated into increased rents.

Having determined the inputs for the cash flow performance measurement model, it is not a difficult exercise to run the model to assess either a change in value or rate of return. However, a further risk assessment step should be incorporated to profile the volatility of the risk in the exercise.

The results of the case study exercise demonstrate that the triple bottom line assessment is achievable and that, based on current market evidence, the difference between the returns achievable on an existing prime grade office building and a similar building, which is environmentally and socially enhanced, is minimal. However, indicators of future demand suggest that sustainability enhancement will, in the future, provide a better return from investment property.

\section{REFERENCES}

Bakens, W., Foliente, C. and Jasuja, M. (2005) Engaging stakeholders in performancebased buildings: lessons from the Performance-Based Building Network, Building Research and Information, 33(2), pp.149-158.

BOMA/ULI (1999) What office tenants want, BOMA/ULI Office Tenant Survey Report, ref www.boma.org, item \#159-TENANT-029.

Boyd, T. P. (2003) Model consistency and data specification in property DCF studies, Australian Property Journal, November, pp. 553-559.

Cassidy, R. (2004) Corporate real estate circa 2010, Building Design and Construction, $45: 6$, pp. 5.

Cole, R.J. (2005) Building environmental assessment methods: redefining intentions and roles, Building Research and Information, 35(5), pp. 455-467.

CRC Construction Innovation Project 2001-11-C, (2004) The Evaluation of the Functional Performance of Commercial Buildings, Final report, CRC-CI, Brisbane.

Dorfling, M. (2004) Buildings put to the greenhouse test, The Australian, 6 May. P. 40.

Environment Australia (2003) Triple Bottom Line Reporting in Australia - A guide to reporting against environmental indicators, June, Dept of the Environment and Heritage, Commonwealth of Australia, Canberra. 
Green Building Council of Australia - Green Start Rating: website www.gbcaus.org.info (July 2006).

Griffiths, J. (2003) Sustainability appraisals - should be an intrinsic part of plan-making, Planning, Issue 1540, pp.28.

Humphreys, M.A. (2005) Quantifying occupant comfort: are combined indices of the indoor environment practicable? Building Research and Information, 33:4, pp. 317-325.

Kats, G. (2003) The Costs and Financial Benefits of Green Buildings, Report to California's Sustainable Building Task Force, October, California.

Lutzkendorf, T and Lorenz, D (2005) Sustainable building investment: valuing sustainable buildings through performance assessment, Building Research and Information, 33(3), pp $212-234$.

Ryder, T. (2003) Facing up to the future, Property Australia, Vol 18, No.4.

Sayce, S. and Ellison, L. (2003) Integrating sustainability into the appraisal of property worth: identifying appropriate indicators of sustainability, paper presented at the AREUEA conference, August 21-3, Skye, Scotland;

Sayce, S, Ellison, L. and Smith, J. (2004) Incorporating sustainability in commercial property appraisal: evidence from the UK, Australian Property Journal, August, pp. $226-233$.

Stern, D.I. (1997) The capital theory approach to sustainability: A critical appraisal, Journal of Economic Issues, 31:1, pp. 145-174.

Von Paumgartten, P. (2003) The business class for high-performance green buildings: Sustainability and its financial impact, Journal of Facilities Management, 2:1, pp. 26-32.

Upstream (2003) Sustainability and the built environment - an agenda for action, RICS Report, June, London. 